Pobrane z czasopisma Annales H - Oeconomia http://oeconomia.annales.umcs.pl Data: 26/04/2023 15:21:46

DOI:10.17951/h.2015.59.3.29

\begin{tabular}{lcc}
\hline \multicolumn{3}{c}{ A N N A L E S } \\
UNIVERSITATIS & MARIAE CURIE-SKŁODOWSKA \\
LUBLIN - POLONIA & \\
VOL. XLIX, 3 & SECTIOH H \\
\hline
\end{tabular}

University of Economics in Katowice, Department of Marketing and Market Research

AGNIESZKA CHĘCIŃSKA-ZAUCHA

agnieszka.checinska-zaucha@ue.katowice.pl

\title{
The Influence of New Media on the Customer's Behavior on the Market
}

Wpływ nowych mediów na zachowanie klientów na rynku

Keywords: new media, relationship marketing, Internet.

Słowa kluczowe: nowe media, marketing relacji, Internet.

JEL Code: M3, M39

\section{Introduction}

The aim of this paper is to determine how new media influence purchasing decisions of customers. Any business activity is eventually dependent on the customer, therefore every company should develop viable strategies for attracting new customers as well as for maintaining the loyalty and increasing the profitability of existing long-time customers. There are various ways to attract new clients. However, what they have in common are: cost, time of acquisition, and effectiveness. The strategy of customer acquisition should be complemented by a strategy for winning their loyalty. There are loyalty programs, but what is equally vital is before and after sales service, as well as nearness to the customer and in-depth analysis of their needs. A tactic, which creates the best opportunity to enhance the loyalty and profitability, consists in expanding the range of products and services being offered to existing customers. In this case, in order to establish and build relationships with customers employing modern technologies and social media is 
extremely important. Of course, which of the three key tasks (getting customers, keeping them and increasing their profitability) should be considered as the most vital, depends on the situation and strategy of the company. The theoretical part of this article is based on the research of the subject literature dealing with the use of new media, whereas the empirical part is based on the results of surveys conducted among the inhabitants of Silesian Voivodeship.

\section{Customer loyalty versus the use of new media tools}

The term of new media is still evolving, and depending on the development of technology it covers different views, solutions, technologies, and concepts. Years ago, the term of new technologies was applied to television and computerization in its initial stage. Today it covers, i.a. global network, digital television, and mobile network. It should be noted that the concept is quite ambiguous: in Polish language this term commonly refers to both the modern tools of communication (mobile phone, other mobile devices, computer, etc.) and new distribution channels (e.g. a global network - the Internet) as well as cutting-edge solutions based on the aforementioned tools and channels (e.g. videoconference) (Witkowska, Cholawo-Sosnowska, 2006, p. 123). Basing on this attempt at classification, while keeping in mind its short lifetime and a mass character of certain solutions, it may be ventured to say that new media such as the Internet or mobile phone, as well as other related tele-information technologies, are solutions which enable quick and very cheap access to information in almost all areas of human activity (Młynarski, 2010). The definition of loyalty, on the other hand, refers to both the continuity of purchase or the use of services from one provider and creating a positive image of the company in the customer's mind. Therefore, it may be concluded that customers evaluate relationships with the service provider in a rational and emotional way. In the rational context, the characteristics of the offered product comprise the price, location, participation in loyalty programs, and availability (Demski, 2003, p. 23). It can be therefore assumed that new media, while becoming a formula for communication in the modern world, are beginning to play a significant role in terms of information, education, aesthetic, or building relationships with customers. Just as in the case of traditional media, messages conveyed by new media shape the attitudes of customers, affect their opinions about reality and their purchasing decisions. However, what differentiates traditional media from new media is the fact that the boundaries between advertising, entertainment and education are disappearing. As a result, information about the company, brand or product influences the awareness and attitudes of the consumer in a non-invasive way. At the same time, the image of the company and the knowledge of its products or services are built. Not so long ago, the Internet was a new, innovative channel of spreading information about a new brand, whereas today it has already become a common tool. Companies entering 
the market have at their disposal tools which enable delivering a clear message to specialized groups of clients. A multitude of tools offer new opportunities to build relationships with the environment, allowing the company to create a bond with the customer basing on a multidirectional communication. Unfortunately, the truth is that companies still are not able to make full use of new opportunities offered by new media (Kucharski, 2011). New opportunities, mainly related to new media, are on many occasions used rather thoughtlessly. It happens that the primary reason for, for example, establishing a profile on Facebook is the presence of their competitors in a particular area. Unfortunately, according to the observations of the author, in many companies, managers do not have time for deeper reflection on the purpose of the tool and for defining the objectives they want to achieve. Nevertheless the employment of tools such as new media is constantly increasing and thus is going to affect the accomplishment of the main objectives of the company - that is, to maintain customer loyalty and to influence their purchasing decisions, e.g. through blogs. The use of new media by companies to a greater extent affects purchasing decisions of customers as it offers the recipient the opportunity for interactive involvement. However, there are still consumers who trust more traditional media such as newspapers and television.

The questions concerning attracting and maintaining a loyal customer have been the subject of researches and analyses for years. This is a problem of the majority of the companies operating in dynamic domestic and international markets. The situation on the market is difficult, mainly due to the fact that the products of competing companies are not much different from one another. Therefore, what is invaluable is the so-called added value which makes one service or product more likely to be purchased than the other. It is extremely difficult to attract new customers nowadays, and it is generally very expensive. It is much cheaper to build strong relationships with the customers the company has already attracted, and to recognize their individual needs and preferences.

Only caring about the customer and focusing on their needs through an effective strategy may provide an organization with an advantage over the competitors. The relationship between the customer and the company is subject to continuous dynamic development and constitutes the cycle of the customer-company relationship. Thus, the ability to attract and retain customers, as well as to identify those in danger of being lost is extremely important. In conjunction with the analysis of the customer value, it provides the answer to the question on how important the dissatisfied client who may take their business somewhere else is, and how much the company should be determined to prevent losing them. Therefore, it is extremely important to have a close link between the relations with the customer, sales modules, marketing and customer service, which are essential from the point of view of effective management. 


\section{Direct studies of the connection between advertising through new media and} making the purchasing decision, and its assessment by the inhabitants of Silesia

\subsection{Methodology}

The main objective of this study was to investigate the influence of new media on purchasing decisions of customers. The survey with the use of questionnaires was conducted in Silesia in January 2014 within a group of 1,073 respondents. The study was based on quota sampling. For the purpose of the study, the technique of handout questionnaires was employed, since it ensures high data collection. A standardized questionnaire with dominant closed questions was used.

The group of women consisted of 591 individuals, representing $55 \%$ of the sample. Almost half, that is $47 \%$ of the respondents, were aged 18-25 (Figure 1). The reason for this is the fact that the generally middle aged and elderly people seem to be very reluctant to take part in the surveys and thus they generally refused to be interviewed.

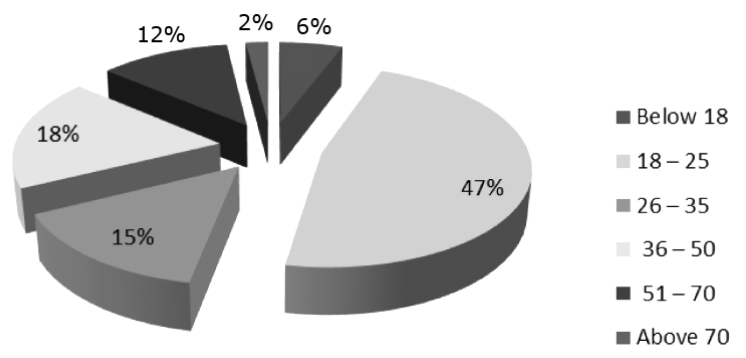

Figure 1. The age of the respondents

Source: author's own calculations based on the data from the survey
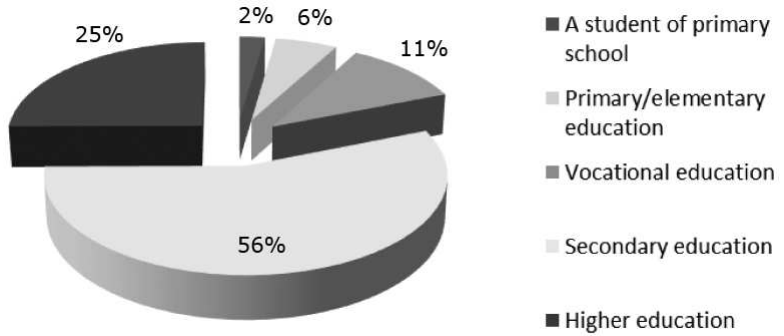

Figure 2. The level of education of the respondents

Source: author's own study

The largest group of respondents were constituted by people with secondary education $(56 \%)$. Every fourth respondent had higher education, and those with vocational education constituted $11 \%$ of the sample (see Figure 2). 
One of the areas assessed by the respondents was to determine the influence of advertisements appearing in the media on their purchasing decisions. The research covered the reaction to advertising through the following media: TV, Internet TV, radio, Internet radio, newspapers, electronic newspapers, banners on the Internet, computer games, e-mail (e.g. newsletters), SMS, MMS, YouTube, blogs, video games, video films (CD, DVD), billboards, digital displays (in shops, in streets), kiosks, traditional mail (advertising letters), social networking sites (Facebook, nk.pl), and Internet forums.

The respondents indicated that, according to their feelings, the greatest impact on their decision to purchase a product or service had advertisements carried by television, newspapers, billboards, and digital displays (see Figure 3).

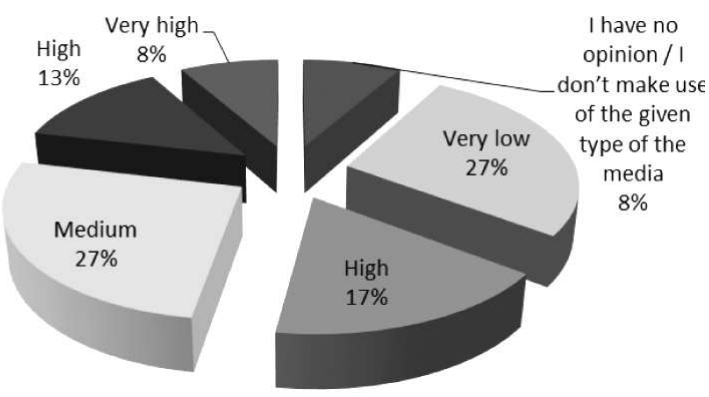

Figure 3. The impact of advertisements through the medium of television on purchasing decisions of the respondents

Source: author's own study

Comparing traditional and modern media, it should be noted that the difference between them in terms of their accessibility and utilization, and thus their influence on the customer is considerably large, due to the fact that many respondents do not have contact with many forms of modern media - e.g. Internet TV, Internet radio, or even an electronic newspaper. According to computer users, banners placed in video games, websites and newsletters also have very little or little influence on their purchasing decisions. The data is presented in Figure 4 below.

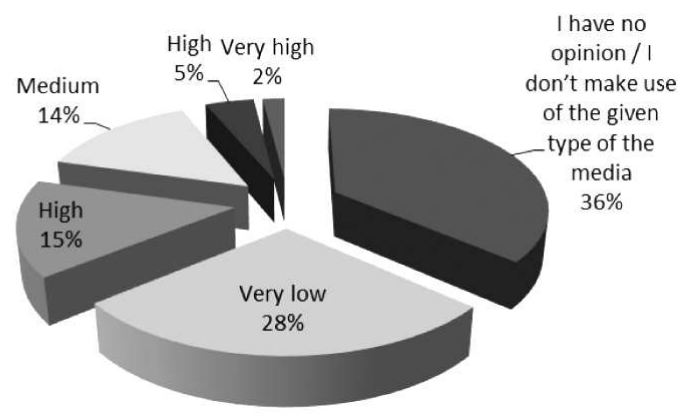

Figure 4. The impact of advertisements on Internet TV on purchasing decisions of the respondents 
Billboards and digital displays persuaded a group of almost $40 \%$ of the respondents into purchasing (very strongly, strongly or rather strongly); advertising via SMS and MMS influenced purchasing decisions of merely $10 \%$ of the respondents in the case of MMS, and $15 \%$ in the case of SMS (see charts 5-8).

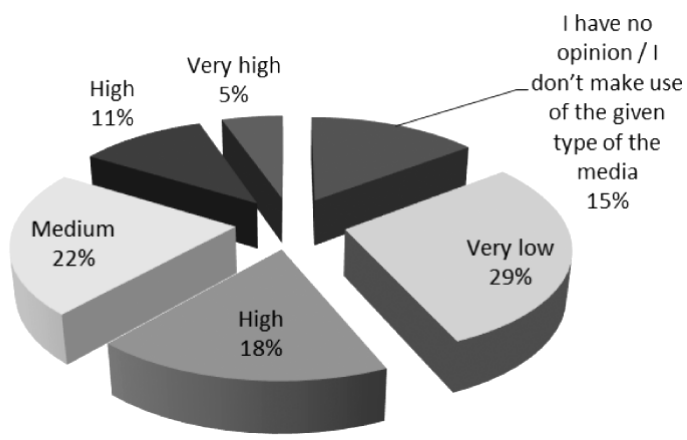

Figure 5. The impact of advertisements on billboards on purchasing decisions of the respondents Source: author's own study

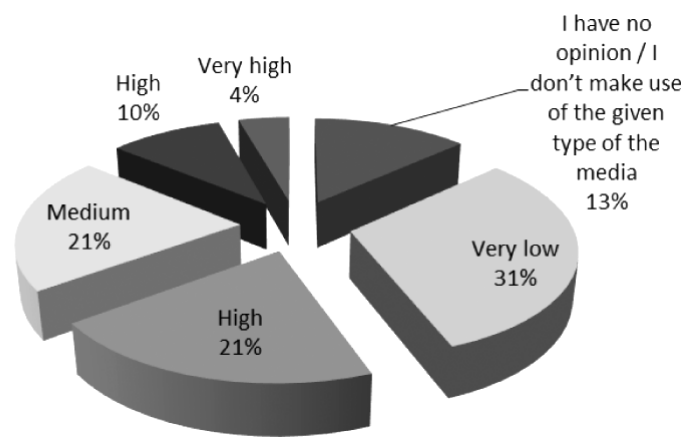

Figure 6. The impact of utilizing digital displays and purchasing decisions of the respondents Source: author's own study

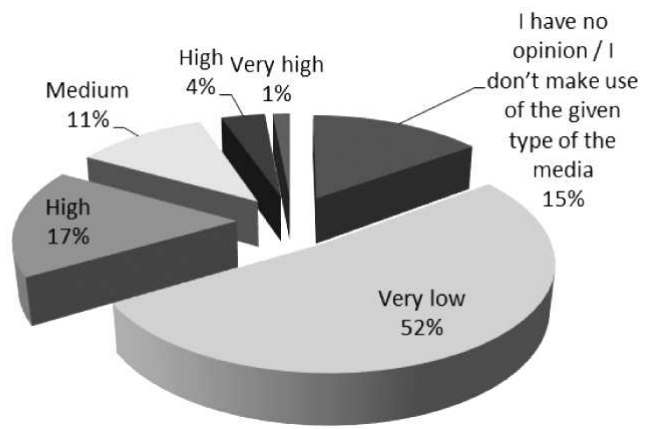

Figure 7. The impact of information received by the respondents via SMS on their purchasing decisions 


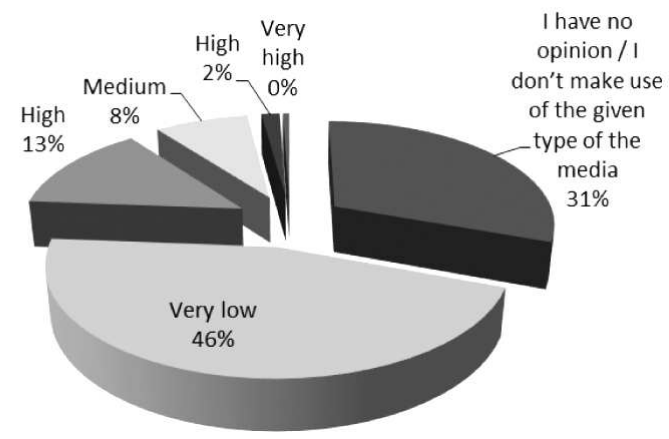

Figure 8. The impact of information received via MMS on purchasing decisions taken by the respondents

Source: author's own study

All this poses the question of to what extent purchasing decisions of the customers are the effect of their searching for information about products or services on blogs, online forums, or through any other media of modern technology, and to what extent they result from their own previous experience or advertisements that reach them through traditional media such as radio, television, billboards, or newspapers.

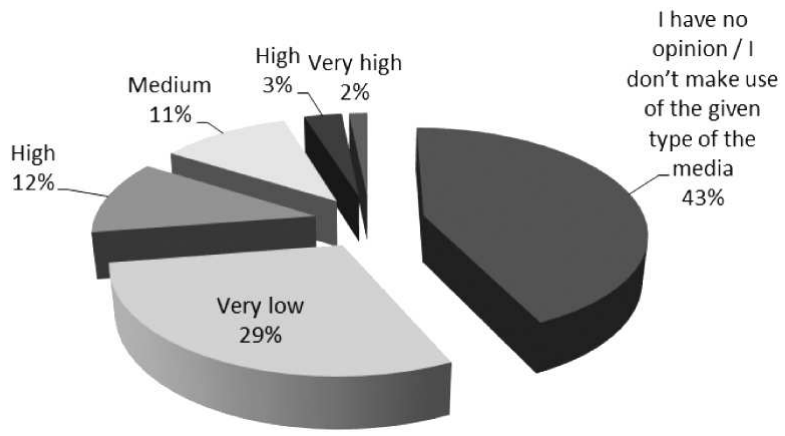

Figure 9. The impact of blogging run by companies on purchasing decisions of the readers

Source: author's own study

Summing up the results of the research it can be concluded that it is a good policy of the company to utilize the potential of new technologies in order to promote its products or services. The technologies, however, are beginning to serve only for information purposes, and do not directly affect the sale of the products or services. Unfortunately, the fact that the company departments are isolated and often even located at a considerable physical distance from one another hamper the exchange of information about customers, especially in the situation when their number is significant. There are also problems with managing the policy of contacting select- 
ed individuals and groups of customers. Meanwhile, effective customer service requires professional knowledge about all of their contacts with employees of the company, the knowledge available in an easy and obvious way and in a relatively short time. The solution to the aforementioned problems may consist in a systemic approach to the management of customer relationships supported by an integrated information system of a very popular today acronym - CRM (Customer Relationship Management). Such a system equipped with a central data repository, that is a data warehouse with the systems of Business Intelligence and Data Mining, is able to provide a full range of information and knowledge about developing the business strategy of an organization. In terms of organization and technology, it is a complete information solution for business, which supports the work of all the departments of the organization dealing directly with the customer. Such a system allows closing the customer service loop, starting with the research related to selecting the potential customer, marketing campaigns, sales, production, logistics, finance, and ending with customer support. Therefore, it enables the agent contacting customers to quickly access detailed information about them at any time. Such solutions facilitate a dynamic relationship between companies and their customers by providing tools that are intuitive for the users and efficient for the company. The employment of such tools is conducive to the transition from the traditional model of marketing, sales and customer service to the model based on tele-information technologies, including the infrastructure of the Internet as a modern medium, and thus creating mobile e'CRMs. This allows for a wider market penetration and better customer service, as well as individualization of products and services for increasingly more sophisticated customer groups. Such systems provide a framework and basic tools for the contact with the customer and the assessment of their needs, whereas the integration of tele-information systems into the organizational Contact Center enables carrying out necessary operational activities in an optimal way, which in turn contributes to fulfilling the needs of the today's demanding customer in the condition of strong competitiveness. This article aims at demonstrating that CRM, as a modern marketing tool for dealing with the customer, is not only an information system, but above all a systemic approach, or, as it is called by people working in management, the adoption of a certain philosophy concerning business strategy which allows creation of new forms of development. The implementation of this concept in practice is, in terms of organization, a difficult and complex process and does not always end successfully. Therefore, while analyzing the causes of the failure of the implementation of systems of this class, what should be indicated is a multiplicity of dysfunctions that occur at the stage of developing the feasibility study and methodologies used, on the one hand, and a range of benefits that can be achieved by the organization due to the implementation of the CRM business concept on the other. 


\section{Conclusions}

Customers play an important role in the functioning of companies, as they provide cash inflows and other values. Activities in the area of building relationships with clients are indicative of the company's development, the growth of its value and profit. Changes in the theory and practice of management are accompanied by changes in technology and society. The use of modern technologies, including the Internet and new media, adds a new dimension to relationships between the company and its customers. In contrast to traditional mass media, new media have become the space allowing multilateral communication, searching for information, completing transactions, and even co-creation of the value. More and more often companies are building relationships using the Internet, as it brings an opportunity for achieving tangible benefits, such as developing innovative business models, keeping down costs, or attracting new customers. The conjunction of the two areas - relationships with customers and using new technologies, presents a very significant challenge for companies. The goal is to create lasting and profitable relationships with customers, often on new, otherwise inaccessible markets. This requires companies to have innovative orientation suitable for building values based on such an extremely valuable resource as the customer's wallet. New media allow the customer to try out and get acquainted with a particular service or product without consequences associated with the purchase. The user can directly and independently enter the sphere of the value and benefits presented by the brand and get to know its functions. The gained experience is virtual, nevertheless the feelings and desires are very real, and what is more important - unsatisfied. Making the dreams come true takes place in the real world, by purchasing decisions. New forms, if they are implemented in a thoughtful manner and in accordance with the expectations of the users, are great instruments building brand awareness and, more importantly, realization of what needs may be satisfied by the brand. Nowadays, the advertisement does not contribute merely to the sale. Its function consists in providing consumers with offered benefits, encouraging them to learn about the product, or increase their knowledge about it, and finally to make them 'brand ambassadors'. The issue of generating sales is only the consequence of a well-matched product and properly implemented communication strategy. After all, new media are virtually the only ones that make it possible to overcome advertising noise and reach the intended recipient with a clear message, while maintaining a full control of tracking the results. The efficiency increases even more if the company contacts potential customers in an unprecedented, unconventional way, and is capable of arousing the customer's interest to such an extent that they are eager to send out links to their friends or post them on their social networking profiles.

The results of the research point out to rather low correlation between advertisements in new media and customers' behavior. Another conclusion resituating from the research is that in further research more people aged above 25 should be addressed. 
Further research should aim at recognizing why the influence of new media on customer's behavior has been rather limited so far, as well as how to improve the effectiveness of employing new media by companies to motivate customer purchasing decisions. On the other hand, what also should be determined is the access to new media, and the reasons for not making purchasing decisions by customers despite their being 'exposed' to new media.

\section{References}

1. Demski T., Lojalność, satysfakcja ich znaczenie i pomiar. StatSoft Polska, 2003, http://www.sixsigma. pl/czytelnia/marketing/znacz.pdf

2. Górniak J., Wprowadzenie do analizy danych w marketingu - część II. Analiza rynku przy użyciu technik wielowymiarowych. Materiały Kursowe. SPSS Polska, Kraków, 2002.

3. Młynarski G., Kontrowersja w reklamie a nowe media, 2010, http://www.grzegorzmlynarski.pl/ kontrowersja-w-reklamie-a-nowe-media/

4. Nunnally J.C, Bernstein I.H., Berge J.M.F., Psychometric theory. McGraw-Hill, New York, 1967.

5. Kucharski K., Nowe media na nowe czasy, http://biznestrend.pl/artykuly/226/Nowe-media-na-noweczasy, 2011.

6. Witkowska M., Cholawo-Sosnowska K., Społeczeństwo informacyjne. Istota, rozwój, wyzwania, WSiP, Warszawa, 2006.

\section{The Influence of New Media on the Customer's Behavior on the Market}

Abstract. The aim of the research, the results of which are presented in this paper, was to determine factors responsible for the effective employment of new media in the process of making purchasing decisions. The article consists of two parts. The first one presents a review of the literature on the subject, the scope of which comprises the issues concerning the employment of new technologies - new media - in building relationships with customers in individual marketing (B2C). The second part contains the results of the research demonstrating the impact of advertisements appearing through new media on purchasing decisions of customers of $\mathrm{B} 2 \mathrm{C}$ market.

\section{Wpływ nowych mediów na zachowanie klientów na rynku}

Abstrakt. Celem badań, których wyniki przedstawione zostały w pracy było określenie jaki wpływ ma rodzaj wykorzystanych nowych mediów na proces podejmowania decyzji zakupowych konsumentów na Śląsku. Artykuł składa się z dwóch części, w pierwszej przybliżono zagadnienia dotyczące wykorzystania nowych mediów w budowaniu relacji z klientami na rynku klienta indywidualnego (B2C). Druga część zawiera wyniki badań dotyczących wpływu reklamy pojawiającej się za pośrednictwem nowych mediów na decyzje zakupowe klientów rynku B2C. 